\title{
Orthotopic liver trans- plantation for carcinoid tumour metastatic to the liver: anesthetic management
}

Rebecca E. Claure MD, David D. Drover MD, Gordon R. Haddow MD,

Purpose: To report the anesthetic management of a patient with carcinoid tumour metastatic to the liver who presented for orthotopic liver transplantation. Anesthetic implications of metastatic carcinoid tumour on liver transplantation and the use of octreotide are discussed.

Clinical features: A 5 I-yr-old woman with intestinal carcinoid tumour metastatic to the liver presented for orthotopic liver transplantation, a recent treatment option for patients with extensive hepatic carcinoid metastases and disabling symptoms unresponsive to conventional therapy. Despite continuous administration of the somatostatin analogue octreotide via a hepatic artery infusate pump, the patient suffered from daily break through symptoms, which included flushing, palpitations, paroxysmal hypertension, and dyspnea. The patient presented to the operating room with sinus tachycardia and severe arterial hypertension. Octreotide and phentolamine were used to prevent further mediator release and to control the paroxysmal hypertension. Midazolam, fentanyl, thiopental, succinylcholine, vecuronium, and isoflurane were used to induce and maintain anesthesia safely. An intravenous octreotide infusion was initiated after induction and continued throughout the case. Infrequent and non-threatening peaks in arterial blood pressure were readily treated with small intravenous doses of vasoactive drugs and octreotide. No other manifestations of the carcinoid syndrome occurred. The patient had an uneventful recovery and was discharged on postoperative day \#6.

Conclusion: The patient safely underwent orthotopic liver transplantation for treatment of symptomatic carcinoid tumour metastatic to the liver. The anesthetic management followed recent recommendations favouring the use of octreotide to prevent patients from becoming symptomatic. Outlined dosing regimen for octreotide provided satisfactory hemodynamic stability.

Objectif : Présenter le traitement anesthésique d'une patiente atteinte d'une tumeur carcinoïde, avec métastase au foie, admise pour une transplantation hépatique orthotopique. Les implications anesthésiques de la tumeur sur la transplantation du foie et l'usage d'octréotide sont étudiées.

Éléments cliniques : Une femme de $5 \mathrm{I}$ ans souffrant d'une tumeur intestinale carcinoïde, avec métastase au foie, s'est présentée pour une transplantation du foie orthotopique, une nouvelle option thérapeutique pour les patients chez qui les métastases carcinoïdes du foie sont étendues et les symptômes invalidants ne sont pas éliminés par la thérapie traditionnelle. Malgré l'administration continue d'un analogue de la somatostatine, l'octréotide, au moyen d'une perfusion insérée dans l'artère hépatique, la patiente souffrait d'une poussée quotidienne de symptômes qui comprenaient des bouffées vasomotrices, des palpitations, de l'hypertension paroxystique et de la dyspnée. À son arrivée à la salle d'opération, la patiente présentait une tachycardie sinusale et une hypertension artérielle sévère. De l'octréotide et de la phentolamine ont été administrées afin d'empêcher la libération ultérieure de médiateur et de contrôler l'hypertension paroxystique. Midazolam, fentanyl, thiopental, succinylcholine, vécuronium et isoflurane ont servi à induire et maintenir une anesthésie en toute sécurité. Une perfusion intraveineuse d'octréotide a été amorcée après l'induction de l'anesthésie et poursuivie tout au long de l'intervention. Des pointes de tension artérielle rares et sans danger ont été traitées facilement avec de faibles doses intraveineuses de médicaments vasoactifs et d'octréotide. Aucune autre manifestation de syndrome carcinoïde n'est survenue. La patiente a connu une récupération sans histoire et a reçu son congé au sixième jour postopératoire.

Conclusion : La patiente a subi en toute sécurité une transplantation du foie orthotopique comme traitement d'une tumeur carcinoïde symptomatique avec métastase au foie. La démarche anesthésique a tenu compte des récentes recommandations favorisant l'usage d'octréotide dans le but d'empêcher les patients de devenir symptomatiques. Un schéma posologique indiqué pour l'octréotide a permis une stabilité hémodynamique satisfaisante.

From the Departments of Anesthesia and Surgery, Stanford University School of Medicine, 300 Pasteur Drive, Stanford, CA 94305 USA. Address correspondence to: Dr. Rebecca E. Claure, Department of Anesthesia, Children's Hospital, 300 Longwood Avenue, Boston, MA 02115 USA. Phone: 617-355-6457; Fax: 617-355-7887.

Accepted for publication December 19, 1999. 


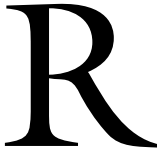

ECENTLY, orthotopic liver transplantation has become a promising treatment for symptomatic carcinoid tumours metastatic to the liver. ${ }^{1,2}$ The anesthetic management of patients with carcinoid syndrome has previously been reviewed. ${ }^{3-5}$ However, the anesthetic management of liver transplantation for carcinoid tumour metastatic to the liver has not been reported. We present the successful management of one such case.

\section{Case report}

A 51-yr-old caucasian woman with intestinal carcinoid tumour metastatic to the liver presented for orthotopic liver transplantation. The patient was initially diagnosed with carcinoid tumour three years before transplantation after presenting with abdominal pain and diarrhea. Symptoms progressed to include flushing, palpitations, paroxysmal hypertension, and shortness of breath. These symptoms escalated in frequency and severity. Treatment included the somatostatin analogue octreotide, (via a hepatic artery infusate pump at 400 $\mu \mathrm{g} \cdot \mathrm{day}^{-1}$ and $50 \mu \mathrm{g} s c$ every two to three hours for break-through symptoms). Urinary 5-HIAA, a serotonin metabolite, remained elevated. An abdominal CT scan revealed two large lesions in the liver. A CT of the thorax, abdomen, and pelvis did not demonstrate any further metastatic disease. A laparotomy allowed resection of the primary carcinoid tumour in the jejunum, but not the intended partial resection of the liver because the metastatic lesions were distributed diffusely throughout the liver.

The patient $(91 \mathrm{~kg}, 164 \mathrm{~cm})$ was admitted for liver transplantation. Past medical history and physical examination were unremarkable, except for the carcinoid syndrome. Medications on admission included phenoxybenzamine (20 $\mathrm{mg}$ bid) and octreotide at the dose outlined above. Platelet count, coagulation profile, and electrolyte panel were normal. The hematocrit was $43 \%$. A chest $x$-ray was unremarkable. The ECG showed sinus tachycardia ( 105 beats. $\mathrm{min}^{-1}$ ) with a left anterior fascicular block. A preoperative echocardiogram showed no evidence of cardiac valvular disease. The mean arterial blood pressure was 150 mmHg (200/118).

On admission to the operating room, the patient received $3 \mathrm{mg}$ midazolam iv for anxiolysis since stress can trigger mediator release from carcinoid tumour cells. ${ }^{3}$ A total of $10 \mathrm{mg}$ phentolamine $i v$ was given to control hypertension. Subcutaneous and intravenous boluses of $50 \mu \mathrm{g}$ octreotide were also injected. Anesthesia was induced with $250 \mu \mathrm{g}$ fentanyl, and 400 mg thiopental, followed by $120 \mathrm{mg}$ succinylcholine $i v$. After induction, an octreotide infusion was started at
$50 \mu \mathrm{g} \cdot \mathrm{hr}^{-1}$ and continued throughout the case. Anesthesia was maintained with midazolam, fentanyl, isoflurane, and vecuronium. Routine lines and monitors included an arterial and central venous line, a pulmonary artery catheter, and a transesophageal echocardiogram.

The mean arterial pressure (MAP) decreased to 90 $\mathrm{mmHg}$ on induction and varied mainly between 85 and $110 \mathrm{mmHg}$ during the pre-anhepatic phase. The occasional peaks in MAP appeared to be related to surgical manipulation of the liver. On two such occasions, the MAP increased to $130 \mathrm{mmHg}$ and $50 \mu \mathrm{g}$ octreotide $i v$ was injected, once in combination with 5 mg phentolamine, and once with $100 \mathrm{mg}$ esmolol. On both occasions, the MAP decreased to approximately $100 \mathrm{mmHg}$ within minutes. Peaks in MAP were not accompanied by changes in ventilation pressures or flushing.

Upon clamping of the vena cava (anhepatic phase), the MAP decreased to 45-50 $\mathrm{mmHg}$. The patient's blood loss was between 1000-1500 ml, and fluid replacement up to that point consisted of $1750 \mathrm{ml}$ albumin $5 \%$ and $3500 \mathrm{ml}$ crystalloid. A first decrease in MAP was successfully restored with $100 \mu \mathrm{g}$ of phenylephrine $i v$. A second decrease could not be restored with $100 \mu \mathrm{g}$ phenylephrine $i v$ followed by $200 \mu \mathrm{g}$. At that point $50 \mu \mathrm{g}$ octreotide was injected followed by $10 \mu \mathrm{g}$ epinephrine. The MAP recovered to about $90 \mathrm{mmHg}$. The patient was hemodynamically stable for the remainder of the anhepatic phase.

Unclamping of the portal vein (post-anhepatic phase) and the hepatic artery did not cause hemodynamic instability. The remainder of the operation was uneventful. The octreotide infusion was weaned on postoperative day \#3. At that time liver function was considered adequate (bile production and coagulation tests) to allow clearance of mediators from remaining and unrecognized intestinal carcinoid tumour cells. The patient was discharged after an uneventful course on postoperative day \#6. An episode of acute rejection six weeks postoperatively was treated successfully. Since then, the patient has remained asymptomatic until the last follow-up visit six months after surgery. Urinary 5HIAA levels have remained within normal limits.

\section{Discussion}

Carcinoid tumours are slow growing neuroendocrine tumours (incidence $0.01-0.001 \%$ ) that arise most commonly from the gastrointestinal tract. ${ }^{6,7}$ In about $2 \%$ of carcinoid tumours, the carcinoid syndrome develops due to the release of mediators not cleared by the liver. ${ }^{6}$ This is seen in patients with liver metastases or tumour locations not draining into the portal venous system. 
Clinical manifestations include symptoms of gastrointestinal hypermotility and vasomotor instability. Symptoms such as nausea, vomiting, diarrhea, cutaneous flushing, hypertension, and hypotension are seen in about $80 \%$ of patients. ${ }^{5}$ Cardiac involvement, including pulmonic or tricuspid valve fibrosis and the occurrence of tachyarrhythmias, is seen in about $40 \%$ of patients. ${ }^{5}$ Bronchospasm, hepatomegaly, and hyperglycemia are less common symptoms. ${ }^{3,5}$

Orthotopic liver transplantation is a recent treatment option for patients with extensive hepatic carcinoid metastases and disabling symptoms. Although still controversial as an indication, liver transplantation appears to result in a prolonged disease-free interval and a longer survival, as well as in a considerable palliation of symptoms. ${ }^{8,9}$ A recent multicentre study showed a five year survival rate of $69 \%$ in metastatic carcinoid tumours .2 This is considerably higher than the five year survival rate of $25 \%$ after nontransplant treatment. ${ }^{10}$

Approximately 20 different mediators released from carcinoid tumour cells are known. The most important ones contributing to the carcinoid syndrome appear to be serotonin, histamine, and the kinin peptides. ${ }^{3}$ In the past, anesthetic management has focused on blocking histamine and serotonin receptors and avoiding drugs facilitating the release of mediators from tumour cells. Drugs thought to trigger mediator release include the opioids meperidine and morphine, the neuromuscular relaxants atracurium and mivacurium, and the catecholamines, including medications which induce their release. The use of thiopental has been discouraged by some because in vitro studies have demonstrated a dose dependent histamine release from skin mast cells. ${ }^{3,4,11}$ However, thiopental triggered histamine release seems to be of minimal importance in the clinical setting. ${ }^{11}$ The use of succinylcholine has also been discouraged because the increase in intra-abdominal pressure resulting from muscular fasciculations could potentially trigger mediator release. A recent review showed no evidence to support this view and we chose to use succinylcholine secondary to a potentially difficult airway and for a rapid sequence intubation. ${ }^{3}$ There were no adverse effects.

More recently, anesthetic management of carcinoid syndrome has focused on preventing mediator release from carcinoid tumour cells with the somatostatin analogue octreotide. It has been suggested that the use of octreotide renders the administration of drugs previously used in the management of carcinoid syndrome superfluous. ${ }^{12,13}$ These drugs were used to block the action of mediators already released into the circulation and included serotonin and histamine antagonists, kallikrein inhibitors, and steroids among others. ${ }^{3,4}$ However, octreotide appears to be the most efficacious treatment for carcinoid syndrome reducing symptoms in more than $70 \%$ of patients. ${ }^{14,15}$ Serotonin antagonists were used in the past with limited success but may still have a role as a second line treatment if octreotide therapy fails. Other pharmacological interventions suppressed symptoms only occasionally, and often resulted in significant side effects. ${ }^{14,15}$

The octreotide dosing regimen chosen for perioperative management consisted of $50 \mu \mathrm{g}$ and a $50 \mu \mathrm{g}$ iv injection prior to incision, followed by a continuous iv infusion of $50 \mu \mathrm{g} \cdot \mathrm{hr}^{-1}$, and additional $50 \mu \mathrm{g}$ boluses to treat episodes of hemodynamic instability. The outlined dosing regimen seems to be the best documented. ${ }^{13,16,17}$ However, the optimal dose of octreotide has not been studied systematically. Following these recommendations, there were still acute increases in blood pressure that appeared related to increased surgical manipulation of the liver. However, such changes were never threatening. On two instances, when the mean arterial pressure (MAP) increased to $130 \mathrm{mmHg}$, it returned to baseline within minutes after an additional $50 \mu \mathrm{g}$ octreotide $i v$. Doses of either phentolamine or esmolol were concomitantly administered and therefore the reduction in blood pressure cannot solely be attributed to octreotide. Vasoactive drugs were co-administered with octreotide to abolish the hypertension quickly. There is at least one report indicating a delay of several minutes before octreotide became fully effective after intravenous administration. ${ }^{3}$

The anhepatic and post-anhepatic phases were uneventful. Contrasting with the pre-anhepatic phase, the blood pressure did not show marked variations. The exclusion of the liver from the systemic circulation during the anhepatic phase may explain this. For the same reason, epinephrine administration during the anhepatic phase may have been safe. However, in the postanhepatic phase the transplanted liver may not have been able to metabolize mediators from remaining tumour cells draining into the portal circulation. For this reason the octreotide infusion was continued throughout surgery and into the intensive care unit stay.

Both crystalloid and colloid solutions (albumin 5\%) were used for intraoperative fluid resuscitation. The use of albumin may be questioned by some because of the potential risk of transmitting an infectious disease, either viral or via prions. However, the use of heat pasteurized albumin has an excellent safety record. ${ }^{18,19}$ Currently, the concerns about transmitting an infectious disease via albumin seem mainly theoretical. Therefore, the use of albumin still seems appropriate for selected cases. 
In summary, we present a patient safely undergoing orthotopic liver transplantation for treatment of metastatic carcinoid syndrome. The anesthetic management with respect to the carcinoid syndrome followed more recent recommendations favoring the use of octreotide to prevent the release of mediators. This regimen provided a baseline of hemodynamic stability. Infrequent and non-threatening peaks in blood pressure were easily treated with vasoactive drugs.

\section{References}

1 Coperchini $M L$, Jones $R$, Angus $P$, et al. Liver transplantation in metastatic carcinoid tumour. Aust N Z J Med 1996; 26: 702-4.

2 Le Treut YP, Delpero JR, Dousset B, et al. Results of liver transplantation in the treatment of metastatic neuroendocrine tumors. A 31-case French multicentric report. Ann Surg 1997; 225: 355-64.

3 Veall GRQ Peacock JE, Bax NDS, Reilly CS. Review of the anaesthetic management of 21 patients undergoing laparotomy for carcinoid syndrome. Br J Anaesth 1994; 72: 335-41.

4 Vaughan DJA, Brunner MD Anesthesia for patients with carcinoid syndrome. Int Anesthesiol Clin 1997; 35: 129-42.

5 Melnyk DL. Update on carcinoid syndrome. AANA J 1997; 65: 265-70.

6 Godwin JD II. Carcinoid tumors. An analysis of 2,837 cases. Cancer 1975; 36: 560-9.

7 Creutzfeldt $W$. Historical background and natural history of carcinoids. Digestion 1994; 55(Suppl 3): 3-10.

8 Frilling A, Rogiers X, Knöfel WT, Broelsch CE. Liver transplantation for metastatic carcinoid tumors. Digestion 1994; 55(Suppl 3): 104-6.

9 Dousset B, Saint-Marc O, Pitre J, Soubrane O, Houssin $D$, Chapuis $\Upsilon$. Metastatic endocrine tumors: medical treatment, surgical resection, or liver transplantation. World J Surg 1996; 20: 908-15.

10 McDermott, EWM, Guduric B, Brennan MF. Prognostic variables in patients with gastrointestinal carcinoid tumours. Br J Surg 1994; 81: 1007-9.

11 Stoelting RK Pharmacology and Physiology in Anesthesia Practice, 2nd ed. Pennsylvania: J.B. Lippincott Company, 1991.

12 Parris WCV, Oates JA, Kambam J, Shmerling R, Sawyers JF. Pre-treatment with somatostatin in the anaesthetic management of a patient with carcinoid syndrome. Can J Anaesth 1988; 35: 413-6.

13 Stoelting $R K$ Anesthesia and Co-existing Disease, 3rd ed. New York: Churchill Livingstone Inc, 1993.

14 Caplin ME, Buscombe JR, Hilson AJ, Jones AL, Watkinson AF, Burroughs AK Carcinoid tumour. Lancet 1998; 352: 799-805.
15 Gregor $M$. Therapeutic principles in the management of metastasising carcinoid tumors: drugs for symptomatic treatment. Digestion 1994; 55(Suppl 3): 60-3.

$16 \mathrm{Katz} M D$, Erstad BL. Octreotide, a new somatostatin analogue. Clin Pharm 1989; 8: 255-73.

17 Marsh HM, Martin JK, Kvols LK, et al. Carcinoid crisis during anesthesia: successful treatment with a somatostatin analogue. Anesthesiology 1987; 66: 89-91.

$18 \mathrm{McClelland} \mathrm{DBL}$. Safety of human albumin as a constituent of biologic therapeutic products. Transfusion 1998; 38: 690-9.

19 Erstad BL. Viral infectivity of albumin and plasma protein fraction. Pharmacotherapy 1996; 16: 996-1001. 